\title{
KeWENANGan PENYIDIK PEgaWAI NegerI SIPIL DALAM PENYIDIKAN KASUS KORUPSI
}

\author{
Muhammad Sodikin $\quad$ Desa Kalibader Genteng \\ m.sodikin@yahoo.com 1 Banyuwangi
}

\begin{abstract}
This article focuses on the discussion about the authority of the civil government employee in the investigation of corruption cases on the fiqh murâfa'ât (Islamic criminal procedure law) perspective. The authority of the civil government employee investigator as stipulated in PP. No. 43 Year 2012 has similarities to al-muhtasib in term of authority and duty to oversee the enactment of the law and to maintain the public order. In addition, there are also similarities between the verification system of Islamic Criminal Procedure Law and the Criminal Procedure Judicial Corruption in term of proof, namely proof imposed on the plaintiff. The author recommends to the law enforcement official, particularly the civil government employee investigator in the Anti-Corruption Commission to be more serious in handling corruption and using a system of proof on the offense gratification rather than using the conventional method. This meant that the state's budget which has been corrupted may be returned to the state.
\end{abstract}

Keywords: Authority, investigator, civil government employee, Islamic criminal procedure law.

Abstrak: Artikel ini membahas tentang kewenangan Penyidik Pegawai Negeri Sipil dalam penyidikan kasus korupsi perspektif fiqh murâfa'ât. Kewenangan Penyidik Pegawai Negeri Sipil (PPNS) sebagaimana yang diatur dalam PP. No. 43 Tahun 2012 mempunyai persamaan dengan alMuhtasib dalam hal kewenangan dan tugas untuk mengawasi berlakunya undang-undang dan menjaga ketertiban umum. Selain itu dalam sistem pembuktian Hukum Acara Pidana Islam dan Hukum Acara Peradilan Tindak Korupsi (Tipikor) ada persamaan dalam hal pembuktian, yaitu bukti dibebankan pada pihak penggugat. Penulis merekomendasikan kepada aparat penegak hukum, khususnya Penyidik Pegawai Negeri Sipil (PPNS) pada Komisi Pemberantasan Korupsi agar lebih serius dalam menangani perkara korupsi dan menggunakan sistem pembuktian terbalik pada delik gratifikasi dari pada menggunakan metode biasa. Hal ini dimaksudkan agar anggaran negara yang dikorupsi dapat dikembalikan pada negara.

Kata Kunci: Kewenangan, penyidik, Pegawai Negeri Sipil, fiqh murâfa'ât 


\section{Pendahuluan}

Berdasarkan isinya, hukum dapat dibedakan menjadi dua, yaitu hukum publik dan hukum privat. ${ }^{1}$ Yang kali pertama melakukan pembagian tersebut adalah Ulpianus. Menurut Ulpianus yang dikutip oleh Peter Mahmud Marzuki bahwa hukum publik berkaitan dengan fungsi negara,. sedangkan hukum privat berkaitan dengan kepentingan individu. ${ }^{2}$ Hukum publik ini adalah keseluruhan peraturan yang merupakan dasar negara dan mengatur pula bagaimana caranya negara melaksanakan tugasnya. Sedangkan hukum privat adalah hukum antar perorangan yang mengatur hak dan kewajiban perorangan yang satu terhadap yang lain di dalam hubungan keluarga dan dalam pergaulan masyarakat. Pelaksanaannya diserahkan kepada masing-masing pihak. ${ }^{3}$

Hukum pidana termasuk dalam lingkup hukum publik yang menentukan perbuatan-perbuatan apa atau siapa sajakah yang dapat dipidana serta sanksi-sanksi apa sajakah yang dicamtumkan dalam perundang-undangan. ${ }^{4}$ Hukum pidana yang berlaku di Indonesia sekarang ini adalah hukum pidana yang telah dikodifikasi, yaitu sebagian besar dari aturan-aturannya telah disusun dalam satu kitab undangundang (wetboek), yang dikenal dengan KUHP (Kitab Undang-Undang Hukum Pidana). ${ }^{5}$ Di samping kodifikasi KUHP ada yang disebut perundang-undangan tersendiri yaitu tindak pidana khusus. Menurut Pompe, sebagaimana dikutip oleh Andi Hamzah, ia menyebut dua kriteria yang menunjukkan hukum pidana khusus itu, yaitu pertama orang-orangnya yang khusus, maksudnya subyeknya atau pelakunya yang khusus dan yang kedua ialah perbutannya yang khusus. Contoh tindak pidana khusus pertama ialah hukum pidana militer, karena orangorangnya yang khusus, yaitu hanya golongan militer. Contoh yang kedua, tindak pidana fiskal untuk delik-delik pajak, yang berarti perbuatan menyelundupkan pajak merupakan perbuatan khusus. ${ }^{6}$

Pada mulanya, istilah korupsi di Indonesia bersifat umum, baru kemudian menjadi istilah hukum sejak dirumuskannya pengaturan penguasa militer No. PRT/PM/06/1957 tentang korupsi. Konsideren

\footnotetext{
${ }^{1}$ Titik Triwulan Tutik, Pengantar Ilmu Hukum (Jakarta: Prestasi Pustaka Publisher, 2006), 197.

${ }^{2}$ Peter Mahmud Marzuki, Pengantar Ilmu Hukum (Jakarta: Kencana, 2009), 211.

${ }^{3}$ Sudikno Mertukusumo, Mengenal Hukum (Yogyakarta: Liberty, Cet.II, 1999), 122.

${ }^{4}$ Ibid.

${ }^{5}$ Moeljatno, Asas-Asas Hukum Pidana (Jakarta: Rineka Cipta, 1993), 16.

${ }^{6}$ Andi Hamzah, Perkembangan Hukum Pidana Khusus (Jakarta: Rineka Cipta, 1991), 1.
} 
peraturan tersebut menyebutkan. "bahwa berhubung dengan tidak adanya kelancaran dalam usaha-usaha memberantas perbuatan-perbuatan yang merugikan keuangan dan perekonomian negara yang oleh khalayak ramai di namakan korupsi, perlu segara menetapakan suatu tata kerja untuk dapat menerobos kemacetan dalam usaha memberantas korupsi...."

Kata korupsi berasal dari bahasa Latin corruption atau corruptus. Selanjutnya disebutkan pula bahwa corruption itu berasal dari suatu kata latin yang lebih tua yaitu corrumpere. Dari bahasa Latin itulah turun kebanyakan bahasa Eropa seperti Inggris, yaitu corruption, corrupt, Prancis, yaitu corruption, Belanda, corruptive (korruptie). Lalu bahasa Belanda inilah yang turun ke Indonesia, yaitu "korupsi". Arti harfiah dari kata tersebut ialah kebusukan, keburukan, kebejatan, ketidak jujuran, dapat disuap, tidak bermoral, penyimpangan dari kesucian, dan kata-kata atau ucapan yang menghina atau menfitnah. ${ }^{8}$

Berdasarkan ketentuan pasal 2 ayat (1) dan pasal 3 UU No. 31 Tahun 1999 jo.UU No. 20 Tahun 2001 tentang Tindak Pidana Korupsi, dalam hal ini unsur-unsur tindak pidana korupsi adalah (1) setiap orang, yang (2) melakukan perbutan melawan hukum, (3) memperkaya diri sendiri, dan (4) merugikan keuangan negara. ${ }^{9}$

Pasal 2 ayat (1) UU No. 31 Tahun 1999 jo. UU No. 20 Tahun 2001 berbunyi:

"Setiap orang yang secara melawan hukum melakukan perbuatan memperkaya diri sendiri atau orang lain atau suatu korporasi yang dapat merugikan keuangan negara atau perekonomian negara....". ${ }^{10}$

Pasal pasal 3 UU No. 31 Tahun 1999 jo. UU No. 20 Tahun 2001 berbunyi:

"Setiap orang yang dengan tujuan menguntungkan diri sendiri atau orang lain atau suatu korporasi, menyalagunakan wewenang, kesempatan, atau sarana yang ada padanya karena

\footnotetext{
${ }^{7}$ Abdul Aziz Dahlan (et al), Ensiklopedi Hukum Islam, jilid III (Jakarta: Icthiar Baru van Hoeve, Cet. IV, 2003), 974.

8 Andi Hamzah, Pemberantasan Korupsi Melalui Hukum Pidana Nasional dan Internasional (Jakarta: Raja Grafindo Persada, Cet. IV, 2008), 4-5

9 Ibid., 124.

${ }^{10} \mathrm{lbid}$.
} 
jabatan atau kedudukannya yang dapat merugikan keuangan negara atau perekonomian negara ...". ${ }^{11}$

Adapun sanksi hukum yang dapat dikenakan kepada tindak pidana korupsi (Tipikor) berupa pidana penjara dan pidana denda (diatur dalam pasal 5, pasal 6, pasal 7, pasal 8, pasal 9, pasal 10, pasal 11, pasal 12, pasal 12B, dan pasal 12C UU No. 31 Tahun 1999 jo. UU No. 20 Tahun 2001) ${ }^{12}$.

Dalam pasal 1 angka 1 KUHAP dinyatakan bahwa yang dimaksud dengan penyidik adalah pejabat polisi negara atau pejabat pegawai negeri sipil tertentu yang diberi wewenang khusus oleh undang-undang untuk melakukan penyidikan. ${ }^{13}$

Kewenangan pejabat penyidik ditetapkan dalam pasal 7 KUHAP (Undang-undang No. 8 Tahun 1981 tentang Hukum Acara Pidana). Kewengan tersebut terdiri dari: ${ }^{14} 1$. Menerima laporan atau pengaduan dari seorang tentang adanya tindak pidana; 2. Melakukan tindakan pertama pada saat ditempat kejadian; 3. Menyuruh berhenti seorang tersangka dan memeriksa tanda pengenal diri tersangka; 4. Melakukan penangkapan, penahanan, penggeledahan, dan penyitaan; 5. Melakukan pemeriksaan dan penyitaan surat; 6. Mengambil sidik jari dan memotret seseorang; 7. Memanggil orang untuk didengar dan diperiksa sebagai tersangka atau saksi; 8. Mendatangkan orang ahli yang diperlukan dalam hubunganya dengan pemeriksaan perkara; 9. Mengadakan penghentian penyidikan; 10. Mengadakan tindakan lain menurut hukum yang bertanggung jawab.

Dari redaksi pasal 7 ayat 1 KUHAP,ternyata bahwa kewenangan yang diatur dalam pasal tersebut adalah kewenangan penyidik sebagai mana dimaksud pasal 6 ayat 1 huruf a KUHAP, yaitu penyidik polri, sedangkan kewenanangan sebagaimana dimaksud pasal 6 ayat 1 huruf $b$ (penyidik pegawai negeri sipil) menurut ketentuan pasal 7 ayat 2 diatur sesuai dengan undang-undang yang menjadi dasar hukumnya masingmasing yang dalam pelaksanaan tugasnya berada dibawah koordinasi pejabat penyidik tersebut pada pasal 6 ayat 1 huruf a (penyidik polri). Kewenangan yang dimiliki penyidik pegawai negeri sipil ini merupakan

\footnotetext{
${ }^{11}$ lbid.

${ }^{12}$ Aziz Syamsuddin, Tindak Pidana Khusus (Jakarta: Sinar Grafika, 2011), 17.

${ }^{13}$ Harun M. Husein, Penyidikan dan Penuntutan dalam Proses Pidana (Jakarta: Rineka Cipta, 1991), 87-92.

${ }^{14}$ Ibid.
} 
pendelegasian penyerahan wewenang (untuk membuat "beslit") oleh pejabat pemerintah (pejabat TUN) kepada pihak lain dan wewenang tersebut menjadi tanggung jawab PPNS. ${ }^{15}$ Untuk mendapatkan gambaran itu, kita perlu melihat penjelasan Pasal 7 ayat (2) KUHAP yang berbunyi sebagai berikut: ${ }^{16}$

Yang dimaksud dengan "penyidik dalam ayat ini" adalah, misalnya pejabat bea cukai, pejabat imigrasi dan pejabat kehutanan, yang melakukan tugas penyidikan sesuai dengan wewenang khusus yang diberikan oleh undang-undang yang menjadi dasar hukumnya masing-masing. ${ }^{17}$

Berdasarkan pasal 7 ayat (2) KUHAP, Penyidik Pegawai Negeri Sipil (PPNS) Komisi Pemberantasan Korupsi (KPK), mempunyai wewenang melakukan penyelidikan, penyidikan, dan penuntutan terhadap tindak pidana korupsi dilakukan berdasarkan hukum acara pidana yang berlaku dan berdasarkan Undang-undang Nomor 31 Tahun 1999 tentang Pemberantasan Tindak Pidana Korupsi sebagaimana telah diubah dengan Undang-undang Nomor 20 Tahun 2001 tentang Perubahan atas Undang-undang Nomor 31 Tahun 1999 tentang Pemberantasan Tindak Pidana Korupsi, kecuali ditentukan lain dalam Undang-undang Nomor 30 Tahun 2002 tentang Komisi Pemberantasan Tindak Pidana Korupsi.

Hukum acara yang digunakan dalam pemeriksaan di sidang pengadilan tindak pidana korupsi (Tipikor) pada dasarnya dilakukan sesuai dengan hukum acara pidana yang berlaku, yakni UU No. 8 Tahun 1981 tentang Hukum Acara Pidana (KUHAP), UU No. 31 Tahun 1999 jo. UU No. 20 Tahun 2001 tentang Pemberantasan Tindak Pidana Korupsi (Tipikor) dan UU No. 14 Tahun 1985 jo. UU No. 3 Tahun 2009 tentang Mahkama Agung (pasal 25 UU No. 46 Tahun 2009). ${ }^{18}$ KPK kerap kali dijuluki oleh kalangan hukum sebagai lembaga super body karena wewenang yang dimilikinya luar biasa besar untuk menyidik, dan menuntuk setiap orang, pegawai negeri, penyelenggara negara, dan bahkan korporasi yang diduga telah melakukan tindak

\footnotetext{
${ }^{15}$ Titik Triwulan Tutik, Hukum Tata Usaha Negara dan Hukum Acara Peradilan Tata Usaha Negara Indonesia (Jakarta: Kencana, 2011), 204.

${ }^{16}$ Ibid., 93.

17 Hartono, Penyidikan \& Penegakan Hukum Pidana Melalui Pendekatan Hukum Progresif (Jakarta: Sinar Grafika, 2010), 55.

${ }^{18}$ Aziz Syamsuddin, Tindak Pidana Khusus, 165-166.
} 
pidana korupsi (Tipikor), sehingga menimbulkan kerugian pada keuangan/perekonomian negara. ${ }^{19}$

Dalam sejarah Islam, tercatat peristiwa-peristiwa korupsi. Misalnya,pengawas perbendaharaan negara di masa khalifah Umar ibn Abdul Aziz (63H/628M-102H/720M) memberikan sebuah kalung emas kepada putri khalifah, karena ia menganggap hal itu patut untut menghargai pengorbanan khalifah. Setelah mengetahui, Umar ibn Abdul Aziz marah dan memerintahkan agar saat itu juga kalung tersebut dikembalikan ke baitul mal, karena kalung itu adalah milik negara dan hanya untuk negara lah harta itu boleh digunakan. ${ }^{20}$ Mengenai perbuatan diatas para ulama fiqh sepakat mengatakan bahwa perbuatan itu adalah haram (dilarang) karena bertentangan dengan maq sid alsharî’ah (tujuan hukum Islam). ${ }^{21}$

Pada masa Khalifah Umar ibn Khatab terdapat lembaga yang menangani urusan kriminal dan pidana selain zina, yaitu yang langsung ditangani oleh hakim. Lembaga ini disebut dengan Aḥdâth, yaitu pasukan polisi yang bertugas melindungi masyarakat dari segala hal yang mengganggu ketertiban. Polisi yang bertugas mencegah terjadinya kerusuhan dan menangkap pelaku kiriminal disebut dengan Sâhib alAḥ̂âth. Khalifah Umar telah mengangkat Qadamah ibn Mazam dan Abu Hurairah sebagai pemimpin lembaga kepolisian disamping tugastugas lain yang diserahkan padanya. ${ }^{22}$

Menurut kebanyakan para imam mujtahid, diantaranya Imam Malik dan para pengikutnya, Imam Ahmad dan para pengikutnya, serta pengikut Abu Hanifah, bahwa hakim dan pejabat hukum wajib menahan terdakwa. Imam Ahmad mengatakan bahwa Nabi saw telah menahan terdakwa dalam tindak pidana. Menurutnya, penahanan itu diberlakukan sampai hakim mendapat kepastian dalam perkaranya. Para ulama fiqh berpendapat, bahwa yang berwenang melakukan penahanan terhadap terdakwa dalam tindak pidana ialah Waliy al-Harb, pejabat penyidik, penyidik pembantu, jaksa, dan jaksa pembantu, bukan hakim. Demikian ini menurut pendapat pengikut al-Syafi'i, seperti Abu Abdillah al-Zubairi, dan al-Mawardi, dan yang lainnya, serta segolongan pengikut

\footnotetext{
${ }^{19}$ Ibid., 193.

${ }^{20}$ Dahlan (et al) Ensiklopedi Hukum Islam, 975.

${ }^{21}$ Ibid., 974.

${ }^{22}$ Abdul Manan, Etika Hakim Dalam Penyelenggaraan Peradilan (Suatu Kajian Dalam Sistem Peradilan Islam) (Jakarta: Kencana, 2007), 82-83.
} 
Ahmad, bahkan pengikut Ahmad ini telah menyusun kitab etika hakim. $^{23}$

Sebenarnya embrio wilayah al-hisbah ini sudah ada sejak Nabi saw, yaitu pada suatu hari Nabi melewati setumpukan biji gandum, tangan Nabi sampai pada gandum yang masi basah, maka Nabi berkata, "Hai pedagang gandum, apa ini?" Pedagang gandum berkata, "kehujanan ya Rasulullah." Lalu Nabi berkata kembali, "Kenapa tidak kamu taruh atas saja, sehingga para pembeli mengetahuinya?" Lalu Nabi berkata, "Barang siapa menipu maka bukan termasuk golongan kami." Dalam menegakkan al-hisbah Nabi tidak sendiri, beliau dibantu oleh para sahabat, misalnya setelah Fath al-Makkah, Nabi menugaskan Said ibn Ash ibn Umayyah menjadi pengawas pasar Makkah. ${ }^{24}$

Menurut Imam Al-Mawardi, hisbah berhak dilakukan setiap orang muslim, namun ada perbedaan antara pelaku hisbah secara sukarela (al-Mutatawwi) dengan dengan pelaku hisbah yang diangkat oleh negara (al-Muhtasib). Adapun tugas al-Muhtasib adalah mengawasi berlaku tidaknya undang-undang umum dan adab-adab kesusilaan yang tidak boleh dilanggar oleh semua orang. ${ }^{25}$ Sedangkan tugas lembaga hisbah adalah memberi bantuan kepada orang-orang yang tidak dapat mengembalikan haknya tanpa bantuan dari petugas-petugas al-hisbah. ${ }^{26}$

Berangkat dari hal-hal di atas, maka menarik untuk membahas kewenangan Penyidik Pegawai Negeri Sipil dalam kasus korupsi dalam tinjauan fiqh murâfáât.

\section{Pengertian dan Dasar Hukum Korupsi dalam Hukum Islam}

Dalam hukum Islam makna korupsi tidak dengan jelas disebutkan al-Qur'ân. Akan tetapi bukan berarti Islam tidak memiliki hukum atas perbutan ini (korupsi). Korupsi tergambar dalam beberapa surat dalam Firman Allah swt, diantaranya adalah QS. Al-Bâqarah: 188: ${ }^{27}$

"Dan janganlah sebagian kamu memakan harta sebagian yang lain diantara kamu dengan jalan yang batil dan (janganlah) kamu

\footnotetext{
${ }^{23}$ Ibnu Qayyim Al- Jauziyah, Hukum Acara Peradilan Islam (Yogyakarta: Pustaka Pelajar, 2006), 181-184.

${ }^{24}$ Basiq Djalil, Peradilan Islam (Jakarta: Amza, 2012), 127.

${ }^{25}$ Muhammad Hasbi Ash Shiddieqi, Peradilan dalam Hukum Acara Islam (Semarang: Pustaka Rizki Putra, 1997), 96.

${ }^{26}$ Basiq Djalil, Peradilan Islam, 128.

${ }^{27}$ Yuli Rahmatul Hidayah, Sanksi Tindak Pidana Korupsi Oleh Pegawai Negeri Sipil Ditinjaun Dari Filsafat Hukum Islam (Surabaya: Fakultas Syariah, 2007), 54-56.
} 
membawa (urusan) harta itu kepada hakim, supaya kamu dapat memakan sebagian daripada harta benda orang lain itu dengan (jalan berbuat) dosa, padahal kamu mengetahui." ${ }^{28}$

Ayat tersebut menjelaskan tentang larangan memakan harta orang lain dengan bathil, memakan dalam arti mengambil dan menggunakan suatu yang berharga yang bukan milik dan haknya. Selain itu juga dijelaskan dalam Firman-Nya Q.S. Al-Muțaffifin 1-2:

"Kecelakaan besarlah bagi orang-orang yang curang, (yaitu) orang-orang apabila menerima takaran dari orang lain mereka minta dipenuhi." ${ }^{29}$

Ayat tersebut menjelaskan tentang larangan berbuat curang. Berbuat curang dalam ayat ini adalah dalam timbangan, maka dalam melakukan suatu perbuatan hendaknya dilaksanakan dengan baik sesuai dengan proporsi tanpa mengurangi atau menghilangkan sesuatu yang bukan haknya. Allah juga melarang hamba-Nya berbuat keji yang nampak atau yang sembunyi-sembunyi. Serta melarang merampas sesuatu yang bukan menjadi haknya dengan cara paksa dan tidak benar. Hal ini sebagaimana firman Allah:

"Katakanlah: Tuhanku hanya mengharamkan perbuatan yang keji, baik yang nampak atau pun yang tersembunyi, dan perbuatan dosa, melanggar hak manusia tanpa alasan yang benar, (mengharamkan) mempersekutukan Allah dengan sesuatu yang Allah tidak menurunkan hujjah untuk itu dan (mengharamkan) mengada-adakan terhadap Allah apa yang tidak kamu ketahui." (QS. Al A'raf: 33$)^{30}$

Dari dalil di atas maka ciri-ciri korupsi sebagai berikut:

a. Perbuatan melawan hukum (bathil dan menyalagunakan amanah).

b. Mengambil hak orang lain tanpa alasan yang benar yang dilakukan secara sembunyi-sembunyi atau terang-terangan.

c. Memperkaya diri sendiri atau mengambil harta orang lain dengan jalan yang dilarang olah syara'.

Hukum Islam disyariatkan Allah swt untuk kemaslahatan manusia. Kemaslahatan yang hendak diwujudkan dengan pensyariatan hukum tersebut ialah terpeliharanya harta dari pemindahan hak milik yang tidak menurut prosedur hukum, dan dari pemanfaatannya yang

\footnotetext{
${ }^{28}$ Departemen Pertahanan RI, Al Qur'an Terjemah Indonesia (Jakarta: Depertemen Pertahanan RI, 2001), 52.

${ }^{29}$ Ibid., 1222.

${ }^{30}$ Ibid., 282.
} 
tidak sesuai dengan kehendak Allah swt. Oleh karena itu, larangan mencuri, merampas, mencopet, dan sebagainya adalah untuk memelihara keamanan harta dari pemilikan yang tidak sah. ${ }^{31}$ Ulama fikih telah sepakat mengatakan bahwa perbuatan korupsi adalah haram (dilarang) karena bertentangan dengan maqâsid al-sharî̀ah (tujuan hukum Islam). Keharaman perbuatan korupsi dapat ditinjau dari berbagai segi, antara lain sebagai berikut.

1. Perbuatan korupsi merupakan perbutan curang dan penipuan yang secara langsung merugikan keuangan negara (masyarakat). Allah swt memberi peringatan agar kecurangan dan penipuan itu dihindari, seperti pada firmannya- $\mathrm{Nya}$ :

"Tidak mungkin seorang Nabi berkhianat dalam urusan harta rampasan perang. Barangsiapa yang berkhianat dalam urusan harta perang itu, maka pada hari kiamat ia akan datang membawa apa yang dikhianatkannya itu; kemudian tiap-tiap diri akan diberi pembalasan tentang apa yang ia kerjakan dengan pembalasan setimpal sedang mereka tidak dianiaya”. (QS. 3:161).

2. Perbuatan korupsi yang disebut juga sebagai penyalahgunaan jabatan untuk memperkaya diri sendiri atau orang lain adalah perbuatan mengkhianati amanah yang diberikan masyarakat kepadanya. Berkhianat terhadap amanat adalah perbuatan terlarang dan berdosa seperti yang ditegaskan Allah dalam firmanNya:

"Hai orang-orang yang beriman, janganlah kamu menghianati

Allah dan Rasul (Muhammad) dan (juga) janganlah kamu menghianati amanat-amanat yang dipercayakan kepadamu, sedang kamu mengetahui". (QS. 8:27).

3. Perbuatan korupsi untuk memperkaya diri sendiri dari harta negara adalah perbuatan lalim (aniaya), karena kekayaan negara adalah harta yang dipungut dari masyarakat termasuk masyarakat miskin dan buta huruf yang mereka peroleh dengan susah payah. Oleh karena itu, amat lalim seorang pejabat yang memperkaya dirinya dari harta msyarakat tersebut, Allah menggolongkan orang-orang ini ke dalam golongan orang-orang yang celaka besar, sebagai mana dalam firmanNya:

"Kecelakaan besarlah bagi orang-orang lalim yakni siksaan di hari yang pedih".(QS. 43:65)

\footnotetext{
${ }^{31}$ Abdul Aziz Dahlan, Ensiklopedi Hukum Islam, 974-975.
} 
4. Pemberian fasilitas negara kepada seseorang karena ia menerima suap dari yang menginginkan fasilitas tersebut. Perbutan ini oleh Nabi Muhammad saw disebut laknat seperti dalam sabdanya

"Allah melaknat orang yang menyuap dan menerima suap". (HR. Ahmad ibn Hambal). ${ }^{32}$

\section{Kewenangan Penyidik Pegawai Negeri Sipil Dalam Penyidikan Kasus Korupsi Menurut Pp. No. 43 Tahun 2012}

Mengacu pada pasal 1 ayat (5) Peraturan Pemerintah No. 43 Tahun 2012 tentang Tata Cara Pelaksanaan Koordinasi, Pengawasan, dan Pembinaan Teknis terhadap Kepolisian Khusus, Penyidik Pegawai Negeri Sipil, dan bentuk-bentuk Pengamanan Swakarsa bahwa yang dimaksud dengan Penyidik Pegawai Negeri Sipil adalah pejabat Pegawai Negeri Sipil tertentu yang berdasarkan peraturan perundang-undangan ditunjuk selaku penyidik dan mempunyai wewenang untuk melakukan penyidikan tindak pidana dalam lingkup undang-undang yang mejadi dasar hukumnya masing-masing. ${ }^{33}$

Dasar Hukum Kewenangan Penyidik Pegawai Negeri Sipil (PPNS)

\section{Undang-undang}

Dalam undang-undang No. 8 Tahun 1981 tentang Hukum Acara Pidana (KUHAP) dalam pasal 1 ayat (1) menyatakan bahwa penyidik adalah pejabat Polisi Negara Republik Indonesia atau pejabat Polisi Negara Republik Indonesia atau pejabat Pegawai Negeri Sipil tertentu yang diberi wewenang khusus oleh undang-undamg untuk melakukan penyidikan. Dan dipertegas lagi pada pasal 6 ayat (1) huruf b yang berbunyi penyidik adalah pejabat Pegawai Negeri Sipil tertentu yang diberi wewenang khusus oleh undang-undang. ${ }^{34}$ Dan dalam Undangundang No. 2 Tahun 2002 tentang Kepolisian Negara Republik Indonesia dalam pasal 1 ayat (11) menyebutkan Penyidik Pegawai Negeri Sipil (PPNS) adalah pejabat Pegawai Negeri Sipil tertentu yang berdasarkan peraturan perundang-undangan ditunjuk selaku penyidik dan mempunyai wewenang untuk melakukan penyidikan tindak pidana

\footnotetext{
32 Ibid.

33 Lihat pasal I ayat (5) PP. No 43. Tahun 2012 tentang Tata Cara Pelaksanaan Koordinasi, Pengawasan, dan Pembinaan Teknis terhadap Kepolisian Khusus, Penyidik Pegawai Negeri Sipil, dan Bentuk-Bentuk Pengamanan Swakarsa.

${ }^{34}$ Lihat UU No. 8 Tahun 1981 tentang Hukum Acara Pidana (KUHAP)
} 
dalam lingkup undang-undang yang menjadi dasar hukumnya masingmasing. ${ }^{35}$

\section{Peraturan pemerintah}

Pada pasal 1 ayat (5) No. 43 Tahun 2012 tentang Tata Cara Pelaksanaan Koordinasi, Pengawasan, dan Pembinaan Teknis terhadap Kepolisian Khusus, Penyidik Pegawai Negeri Sipil, dan Bentuk-Bentuk Pengamanan Swarkasa, dalam peraturan ini menyebutkan bahwa Penyidik Pegawai Negeri Sipil (PPNS) adalah pejabat Pegawai Negeri Sipil tertentu yang berdasarkan peraturan perundang-undangan ditunjuk selaku penyidik dan mempunyai wewenang untuk melakukan penyidikan tindak pidana dalam lingkup undang-undang yang menjadi dasar hukumnya masing-masing. ${ }^{36}$

\section{Kewenangan dan Tugas Penyidik Pegawai Negeri Sipil (PPNS)}

Kewenangan pejabat penyidik ditetapkan dalam pasal 7 KUHAP (Undang-undang No. 8 Tahun 1981 tentang Hukum Acara Pidana). Kewengan tersebut antara lain; Menerima laporan atau pengaduan dari seorang tentang adanya tindak pidana, melakukan tindakan pertama pada saat di tempat kejadian, menyuruh berhenti seseorang tersangka dan memeriksa tanda pengenal diri tersangka, melakukan penangkapan, penahanan, penggeledahan, dan penyitaan, melakukan pemeriksaan dan penyitaan surat, mengambil sidik jari dan memotret seseorang, memanggil orang untuk didengar dan diperiksa sebagai tersangka atau saksi, mendatangkan orang ahli yang diperlukan dalam hubunganya dengan pemeriksaan perkara, mengadakan penghentian penyidikan dan mengadakan tindakan lain menurut hukum yang bertanggung jawab.dari redaksi pasal 7 ayat (1) ditas ternyata kewenangan yang diatur dalam pasal tersebut adalah kewenangan penyidik sebagaimana dimaksud pasal 6 ayat (1) huruf a KUHAP, yaitu polri, sedangkan kewenangan penyidik sebagaimana yang dinaksud pasal 6 ayat (1) huruf b Penyidik Pegawai Negeri Sipil (PPNS) menurut ketentuan pasal 7 ayat (2) diatur dengan undang-undang yang menjadi dasar hukumnya masing-masing yang dalam pelaksanaan tugasnya berada dibawah koordinasi penyidik Polri. ${ }^{37}$

\footnotetext{
${ }^{35}$ Lihat UU No. 2 Tahun 2002 tentang Kepolisian Negara Republik Indonesia.

${ }^{36}$ Lihat PP. No. 43 Tahun 2012.

${ }^{37}$ Harun M. Husein, Penyidikan dan Penuntutan, 91-92.
} 
Berdasarkan pasal 7 ayat (2) KUHAP, Penyidik Pegawai Negeri Sipil (PPNS) Komisi Pemberantasan Korupsi (KPK), mempunyai wewenang melakukan penyelidikan, penyidikan, dan penuntutan terhadap tindak pidana korupsi dilakuakn berdasrkan hukum acara pidana yang berlaku dan berdasarkan Undang-undang Nomor 31 Tahun 1999 tentang Pemberantasan Tindak Pidana Korupsi sebagaimana telah diubah dengan Undang-undang Nomor 20 Tahun 2001 tentang Perubahan atas Undang-undang Nomor 31 Tahun 1999 tentang Pemberantasan Tindak Pidana Korupsi, kecuali ditentukan lain dalam Undang-undang Nomor 30 Tahun 2002 tentang Komisi Pemberantasan Tindak Pidana Korupsi.

Dalam penjelasan pasal 38 ayat (1) Undang-undang Nomor 30 Tahun 2002 dijelaskan bahwa; yang dimaksud dengan "yang berkaitan dengan penyelidikan, penyidikan, dan penuntutan" dalam ketentuan ini antara lain, kewenangan melakukan penangkapan, penahannan, penggeledahan, penyitaan, dan pemeriksaan. Penyelidikan, penyidikan dan penuntutan terhadap tindak pidana korupsi dilaksanakan berdasarkan perintah dan bertindak untuk dan atas nama Komisi Pemberantasan Korupsi (KPK). Komisi Pemberantasan Korupsi berwenang mengkoordinasikan dan mengendalikan penyidikan, penyelidikan, dan penuntutan tindak pidana korupsi yang dilakuakn bersama-sama oleh orang yang tunduk pada peradilan militer dan peradilan umum. ${ }^{38}$

\section{Analisis tentang Kewenangan Penyidik Pegawai Negeri Sipil (PPNS) dalam Penyidikan Kasus Korupsi Menurut PP. No. 43 Tahun 2012}

Kewenangan Penyidik Pegawai Negeri Sipil (PPNS) sebagaimana dimaksud pasal 6 ayat 1 huruf b, yakni Penyidik Pegawai Negeri Sipil (PPNS) mempunyai kewenangan berdasarkan oleh undang-undang khusus. Hal mana kewenangan tersebut diatur sesuai dengan undangundang yang menjadi dasar hukumnya masing-masing ${ }^{39}$ lembaga penyidikan kasus korupsi. Dan Kewenangan ini merupakan pendelegasian wewenang yang diberikan oleh undang-undang.

Dengan demikian, Penyidik Pegawai Negeri Sipil (PPNS),

\footnotetext{
${ }^{38}$ Ermansjah Djaja, Meredesaian Pengadilan Tindak Pidana korupsi (Jakarta: Sinar Grafika, 2010), 168-170.

${ }^{39}$ Lihat pasal 7 ayat (2) KUHP dan pasal 5 PP. No. 43 Tahun 2012 tentang Koordinasi, Pengawasan dan Pembinaan Terhadap Kepolisian Khusus, PPNS, dan Bentuk-Bentuk Pengamanan Swarkarsa.
} 
khususnya yang dimiliki KPK mempunyai fungsi dan tugas sebagaimana yang diatur dalam Undang-undang Nomor 31 Tahun 1999 tentang Pemberantasan Tindak Pidana Korupsi sebagaimana telah diubah dengan Undang-undang Nomor 20 Tahun 2001 tentang Perubahan atas Undang-undang Nomor 31 Tahun 1999 tentang Pemberantasan Tindak Pidana Korupsi, kecuali ditentukan lain dalam Undang-undang Nomor 30 Tahun 2002 tentang Komisi Pemberantasan Tindak Pidana Korupsi, dalam aspek kewenangan melakukan penyelidikan, penyidikan dan penuntutan.

Dalam penjelasan pasal 38 ayat (1) Undang-undang Nomor 30 Tahun 2002 dijelaskan bahwa; yang dimaksud dengan kalimat "yang berkaitan dengan penyelidikan, penyidikan, dan penuntutan" dalam ketentuan ini antara lain; kewenangan melakukan penangkapan, penahannan, penggeledahan, penyitaan, dan pemeriksaan. Penyelidikan, penyidikan dan penuntutan terhadap tindak pidana korupsi dilaksanakan berdasarkan perintah dan bertindak untuk dan atas nama Komisi Pemberantasan Korupsi (KPK). Komisi Pemberantasan Korupsi berwenang mengkoordinasikan dan mengendalikan penyelidikan, penyidikan, dan penuntutan tindak pidana korupsi yang dilakukan bersama-sama oleh orang yang tunduk pada peradilan militer dan peradilan umum.

Hukum acara yang digunakan dalam pemeriksaan pada pengadilan tindak pidana korupsi (Tipikor) pada dasarnya dilakukan sesuai dengan hukum acara pidana yang berlaku pada tindak pidana pada umumnya (KUHAP), selain itu juga menggunakan hukum acara yang diatur dalam Undang-undang No. 20 Tahun 2001 tentang Pemberantasan Tindak Pidana Korupsi dan Undang-undang No. 30 Tahun 2002 tentang Komisi Pemberantasan Korupsi (KPK).

Sistem pembuktian yang digunakan di Indonesia adalah sistem pembuktian dengan teori berdasarkan undang-undang secara negatif ${ }^{40}$ yang mana hal itu dapat dilihat berdasarkan pasal 183 (KUHAP) yaitu "Hakim tidak boleh menjatuhkan pidana kepada seseorang kecuali apabila dengan sekurang-kurangnya dua alat bukti yang sah ia memperoleh keyakinan bahwa suatu tindak pidana benar-benar terjadi dan bahwa terdakwalah yang bersalah melakukannya". Dari kalimat

\footnotetext{
${ }^{40}$ Sistem pembuktian yang didasarkan pada undang-undang dan disertai dengan keyakinan hakim atas kebenaran pembuktian dalam hal terjadinya tindak pidana.
} 
tersebut nyata bahwa pembuktian harus didasarkan kepada undangundang. Dalam hal pembuktian kasus korupsi alat bukti yang digunakan adalah alat bukti yang terdapat dalam pasal 184 (KUHAP) yaitu keterangan saksi, keterangan ahli, surat, petunjuk dan keterangan terdakwa. Disamping itu harus disertai dengan keyakinan hakim, karena hukum Indonesia menganut teori pembuktian undang-undang secara negatif.

Sistem pembuktian dalam perkara tindak pidana korupsi (Tipikor) selain berdasarkan kepada Undang-undang No. 8 Tahun 1981 tentang Hukum Acara Pidana (KUHAP) juga berdasarkan kepada hukum pidana formil sebagaimana diatur didalam Undang-undang No. 31 Tahun 1999 tentang Pemberantasan Tindak Pidana Korupsi sebagaimana telah diubah dengan Undang-undang No. 20 Tahun 2001 tentang Perubahan atas Undang-undang No. 31 Tahun 1999 tentang Pemberantasan Tindak Pidana Korupsi, dan Undang-undang No. 30 Tahun 2002 tentang Komisi Pemberantasan Korupsi.

Sistem pembuktian terbalik pada tindak pidana korupsi sebagaimana yang dimaksud dalam pasal 12 B ayat (1) Undang-undang Nomor 20 Tahun 2001 huruf a: Tindak Pidana Korupsi "yang nilainya Rp 10.000.000,00 (sepuluh juta) rupiah atau lebih. Pembuktian bahwa gratifikasi tersebut bukan merupakan suap yang dilakukan oleh penerima gratifikasi dan pembuktian gratifikasi terkait pada pasal 37 Undangundang Nomor 20 Tahun 2001 ayat (1) yang berbunyi: "terdakwa mempunyai hak untuk membuktikan bahwa ia tidak melakukan tindak pidana korupsi”. Di dalam penjelasan pasal 37 Undang-undang Nomor 31 Tahun 1999 dijelaskan sebagai berikut; Ketentuan ini merupakan suatu penyimpangan dari ketentuan Kitab Undang-Undang Hukum Acara Pidana (KUHAP) yang menentukan bahwa jaksa yang wajib membuktikan dilakukannya tindak pidana, bukan terdakwa. Apabila terdakwa dapat membuktikan hal tersebut tidak terbukti melakukan korupsi, penuntut umum masih tetap berkewajiban untuk membuktikan dakwaanya. Ketentuan pasal ini merupakan pembuktian terbalik yang terbatas, karena jaksa masih tetap wajib membuktikan dakwaannya.

Demikian juga dalam penjelasan pasal 37 ayat (1) dan ayat (2) Undang-undang Nomor 20 Tahun 2001 tentang Perubahan atas Undang-undang Nomor 31 Tahun 1999 tentang Pemberantasan Tindak Pidana Korupsi. Pasal ini sebagai konsekuensi berimbang atas penerapan 
pembuktian terbalik terhadap terdakwa. Terdakwa tetap memerlukan perlindungan hukum berimbangan atas pelanggaran hak-hak yang mendasar yang berkaitan dengan asas praduga tak bersalah dan menyalahkan diri sendiri dan ketentuan ini tidak menganut sistem pembuktian secara negatif menurut undang-undang.

Selain itu pada alenia ke-13 penjelasan umum Undang-undang Nomor 31 Tahun 1999 dijelaskan sebagai berikut; Undang-undang ini juga menerapkan pembuktian terbalik yang bersifat terbatas atau berimbang, yakni terdakwa mempunyai hak untuk membuktikan bahwa ia tidak melakukan tindak pidana korupsi dan wajib memberikan keterangan tentang seluruh harta benda istri atau suami, anak dan harta benda setiap orang atau korporasi yang diduga mempunyai hubungan dengan perkara yang bersangkutan, dan penuntut umum tetap berkewajiban membuktikan dakwaannya.

Sebelum terdakwa menggunkan sistem pembuktian terbalik didepan majelis hakim, dan demi mencari kebenaran materiil, maka kewajiban Jaksa Penuntu Umum (JPU), ${ }^{41}$ membacakan dakwaannya. Dakwaan yang dimaksud harus jelas menguraikan perbuatan mana yang telah dilanggar oleh terdakwa, mengambarkan atau menguraikan tentang kejadian-kejadian atau peristiwa, melanggar ketentuan mana, serta apa sanksinya. Pada dasarnya hak yang digugat atau yang didakwa harus diketahui secara rasional, dan berisi tuntutan tentang sesuatu yang jelas, jika yang dituntut tidak jelas maka tuntutan tersebut batal, bukan tidak dapat diterima. Karena tuntutan yang tidak jelas sama halnya dengan tuntutan yang tidak sempurna.

\section{Analisis Fiqh Murâfa'ât terhadap Kewenangan Penyidik Pegawai Negeri Sipil (PPNS) dalam Kasus Korupsi}

Menurut penulis dalam hukum Islam wewenang PPNS mempunyai kemiripan dengan wewenang Muhtasib, sebagaimana pendapat Imam al-Mawardi, lembaga al-hisbah mempunyai tugas: menegakkan hukum, mengawasi subyek hukum agar taat norma hukum,

\footnotetext{
${ }^{41} \mathrm{JPU}$ adalah kepanjangan dari jaksa penuntut umum, dalam Undang-undang No. 16 Tahun 2004 tentang Kejaksaan pada ketentuan umum dijelaskan: "Jaksa adalah pejabat fungsional yang diberi wewenang oleh undang-undang untuk bertindak sebagai penuntut umum dan pelaksana putusan pengadilan yang telah memperoleh kekuatan hukum tetap serta wewenang lain berdasarkan undang-undang. Penuntut umum adalah Jaksa yang diberi wewenang oleh undang-undang ini untuk melakukan penuntutan dan melaksanakan penetapan hakim".
} 
dan membantu orang-orang yang teraniaya untuk mendapatkan haknya. Pada prinsipnya hisbah berhak dilakukan setiap orang muslim. Adapun petugas al-hisbah ada dua macam yang pertama yang disebut alMuhtasib yaitu petugas hisbah yang diangkat oleh negara dan yang kedua al-Mutatawwi yaitu petugas al-hisbah secara sukarela. Kewajiban hisbah bagi al-Muhtasib adalah fardu 'ain, kewajiban seperti mencari pembuktian terjadinya kemungkaran-kemungkaran (kejahatan) yang terjadi di masyarakat, dan memeriksa kebaikan-kebaikan yang ditinggalkan untuk diamalkan.

Adapun tugas al-Muhtasib adalah mengawasi berlaku tidaknya undang-undang umum, adab-adab kesusilaan yang tidak boleh dilanggar oleh semua orang dan melakukan penahanan sementara terhadap tersangka tindak pidana. Sedangkan tugas lembaga al-hisbah adalah amar ma'rûf nahy munkar, baik yang berkaitan dengan hak Allah, hak hamba, dan hak yang bertalian dengan keduanya. Adapun yang berkaitan dengan hak Allah, misalnya; melarang mengkonsumsi minuman keras, melarang melakukan hal-hal yang keji, berbuat zina, mencegah terjadinya korupsi dan gratifikasi. Sedangkan yang berkaitan dengan hak hamba adalah menyangkut kepentingan umum, misalnya; melarang penduduk membangun rumah yang mengganggu kepentingan umum dan melanggar hak-hak sesama tetangga. Dan yang berkaitan dengan hak kedua-duanya (hak Allah dan hamba), misalnya; melarang berbuat curang dalam bermuamalah, seperti jual-beli yang dilarang syariat, penipuan dalam takaran dan timbangan, menegakkan hak asasi manusia seperti mencegah buruh membawa beban di luar batas kemampuannya, melarang pengemudi membawa muatan melebihi kuota.

Dalam beberapa kasus, seorang al-Muhtasib juga bertugas seperti hakim, yaitu pada kasus-kasus tertentu yang memerlukan putusan segera. Hal ini dilakukan karena terkadang ada suatu masalah yang harus segera diselesaikan agar tidak menimbulkan dampak yang lebih buruk. Seorang al-Muhtasib tidak saja menyelesaikan satu sengketa atau mendengar satu pengaduan, dia juga boleh memberi putusan terhadap suatu hal yang masuk ke dalam bidangnya. Akan tetapi, al-Muhtasib tidak mempunyai hak untuk mendengar keterangan-keterangan saksi dalam memutus dalam suatu hukum dan tidak pula berhak menyuruh bersumpah terhadap orang yang menolak suatu gugatan karena yang demikian itu termasuk dalam kewenangan hakim. Jadi, wilayah al-hisbah secara garis 
besarnya menyerupai jawatan penuntut umum, sedangkan al-Muhtasib dapat disamakan dengan penuntut umum, karena mereka adalah orangorang yang bertugas memelihara hak-hak umum dan tata tertib masyarakat. Walaupun dalam beberapa segi terdapat perbedaan, namun secara garis besar dapat dikatakan bahwa tugas al-hisbah di dalam hukum Islam merupakan dasar bagi penuntut umum sekarang ini.

Dalam konteks fungsional, penulis berpendapat bahwa wilayah alhisbah secara garis besar menyerupai jawatan kepolisian, sedangkan alMuhtasib dapat disamakan dengan polisi yang mana keduanya mempunyai kesamaan dalam hal tugas dan kewenangannya. Contoh tugas dan wewenang polisi antara lain; memelihara keamanan dan ketertiban masyarakat, menegakkan hukum dan memberikan perlindungan, pengayoman, dan pelayanan pada masyarakat. ${ }^{42}$ Sedangkan al-Muhtasib mempunyai tugas dan wewenang melarang kemungkaran-kemungkaran yang dilakukan dan menyuruh kebaikankebaikan yang ditinggalkan untuk diamalkan, dan menjatuhkan ta'zîr (sanki disiplin) terhadap kemungkaran-kemungkaran yang terlihat dan mengajak masyarakat menjaga ketertiban umum.

Tindak pidana merupakan perbuatan-perbuatan yang dilarang oleh syara' yang diancamkan oleh Allah swt dengan hukuman hudûd atau ta'zîr. Larangan-larangan itu dapat berupa melakukan perbuatan perbuatan yang dilarang atau meninggalkan perbuatan yang diperintahkan untuk dilaksanakan. Perintah dan larangan merupakan beban-beban (taklîf) syariat. Secara singkat dapat dijelaskan, bahwa suatu perbuatan dianggap delik (jarîmah) bila terpenuhi syarat dan rukun. Adapun rukun jarîmah dapat dikategorikan menjadi dua (2): pertama, rukun umum, artinya unsur-unsur yang harus dipenuhi pada setiap jarîmah. Kedua, unsur khusus, artinya unsur-unsur yang harus terpenuhi pada jenis jarîmah tertentu. ${ }^{43}$

Unsur-unsur tindak pidana (jarîmah) secara umum menurut ulama dari Mesir, Abdul Qadir Audah mengemukan bahwa unsur-unsur umum untuk jarîmah itu ada tiga macam: ${ }^{44}$

\footnotetext{
${ }^{42}$ Lihat pasal 13 UU tentang Kepolisian Negara Republik Indonesia No. 2 Tahun 2002.

${ }^{43}$ Mahrus Munajat, Dekontruksi Hukum Pidana Islam, 9.

${ }^{44}$ Ahmad Wardi Muslich, Pengantar dan Asas Hukum Pidana Islam (Fikih Jinayah) Jakarta: Sinar Grafika, 2004), 28.
} 


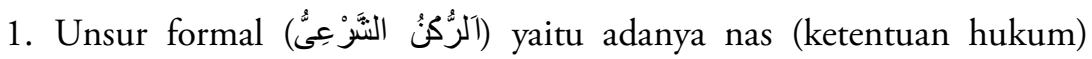
yang melarang perbuatan dan mengancamnya dengan hukuman.

Unsur material (آلرَّكنُ المادِى) yaitu adanya perbuatan seseorang yang melakukan perbuatan yang dilarang, baik berupa melakukan tindakan yang diperintah undang-undang (al-jarîmah al-îjâbiyyah) maupun subyek hukum yang melanggar larangan dalam undang-undang (aljarîmah salbiyyah).

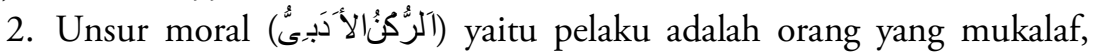
yakni orang yang dapat dimintai pertanggung jawaban atas tindak pidana yang dilakukannya.

Dalam hukum Islam makna korupsi tidak eksplisit disebutkan dalam al-Qur'an. Akan tetapi, bukan berarti Islam tidak memiliki hukum atas perbutan ini (korupsi). Korupsi tergambar dalam beberapa surat seperti dalam Firman Allah swt, sebagai berikut;

"Dan janganlah sebagian kamu memakan harta sebagian yang lain diantara kamu dengan jalan yang batil dan (janganlah) kamu membawa (urusan) harta itu kepada hakim, supaya kamu dapat memakan sebagian daripada harta benda orang lain itu dengan (jalan berbuat) dosa, padahal kamu mengetahui." (QS. AlBâqarah: 188)

Dalam Islam korupsi ada dua macam, yang pertama, ghulûl menurut bahasa adalah khianat, sedangkan menurut istilah, ghulûl yaitu perbuatan seseorang mengambil barang (sesuatu) yang bukan miliknya dengan sembunyi-sembunyi dengan cara yang tidak benar (khianat). Hal kedua, rishwah berasal dari bajasa Arab rashâ, yarshû, rasya, yang berarti "sogokan" atau "bujukan".

Ulama fikih telah sepakat mengatakan bahwa perbuatan korupsi adalah haram (dilarang) karena bertentangan dengan maqâsid al-sharî̉ah (tujuan hukum Islam). Keharaman perbuatan korupsi dapat ditinjau dari berbagai segi, antara lain sebagai berikut.

1. Perbuatan korupsi merupakan perbutan curang dan penipuan yang secara langsung merugikan keuangan negara (masyarakat). Allah swt memberi peringatan agar kecurangan dan penipuan itu dihindari, seperti pada firman-Nya:

"Tidak mungkin seorang Nabi berkhianat dalam urusan harta rampasan perang. Barangsiapa yang berkhianat dalam urusan harta perang itu, maka pada hari kiamat ia akan datang membawa apa yang dikhianatkannya itu; kemudian tiap-tiap diri 
akan diberi pembalasan tentang apa yang ia kerjakan dengan pembalasan setimpal sedang mereka tidak dianiaya”. (QS. 3:161).

2. Perbuatan korupsi yang disebut juga sebagai penyalahgunaan jabatan untuk memperkaya diri sendiri atau orang lain adalah perbuatan mengkhianati amanah yang diberikan masyarakat kepadanya. Berkhianat terhadap amanat adalah perbuatan terlarang dan berdosa seperti yang ditegaskan Allah dalam firman-Nya:

"Hai orang-orang yang beriman, janganlah kamu menghianati Allah dan Rasul (Muhammad) dan (juga) janganlah kamu menghianati amanat-amanat yang dipercayakan kepadamu, sedang kamu mengetahui”. (QS. 8:27).

3. Perbuatan korupsi untuk memperkaya diri sendiri dari harta negara adalah perbuatan lalim (aniaya), karena kekayaan negara adalah harta yang dipungut dari masyarakat termasuk masyarakat miskin dan buta huruf yang mereka peroleh dengan susah payah. Oleh karena itu, amat lalim seorang pejabat yang memperkaya dirinya dari harta msyarakat tersebut, Allah menggolongkan orang orang ini kedalam golongan orang-orang yang celaka besar, sebagai mana dalam firmanNya:

"Kecelakaan besarlah bagi otang-orang lalim yakni siksaan di hari yang pedih”.(QS. 43:65). ${ }^{45}$

Pada prinsip asal beban pembutian adalah hak kedua belah pihak, baik penggugat maupun tergugat. Terutama pihak yang mengaku mempunyai hak atau mendasarkan pada suatu peristiwa untuk menguatkan haknya atau menyangkal hak orang lain. Akan tetapi pembuktian terbalik merupakan wacana baru dalam hukum acara pidana, kusussnya di Indonesia pada pembuktian peradilan tindak pidana korupsi. Hukum pembebanan pembuktian pada Acara Pidana Islam sepenuhnya menekankan pendakwa sebagai satu-satunya pihak yang dibebani pembuktian, baik dalam perkara pidana had, ta'zîr, maupun qiṣâs. Sebagaimana sabda Nabi saw:

"Diriwayatkan al-Bayhaqi dengan sanad yang shahih, bahwasanya

Rasulullah saw bersabda, bukti itu (wajib) atas penggugat dan sumpah itu (wajib) atas pihak yang menolak (pengakuan)" (riwayat al-Bayhaqî).

Dalam konteks pembuktian, menurut penulis, hadis tesebut dimaksudkan bahwa untuk mendapatkan putusan hukum yang sesuai

45 Ibid. 
dengan petitum gugatannya, seorang penggugat dalam hal ini jaksa penuntut umum harus mengemukakan bukti-bukti yang membenarkan dalil-dalil gugatannya. Bukti-bukti yang dimaksud adalah tentunya berdasarkan ketentuan peraturan perundang-undangan tentang macammacam alat bukti. Dengan kata lain, tergugat atau terdakwa sama sekali tidak diberikan kewajiban untuk membuktikan secara terbalik terhadap apa yang didakwakan padanya, karena pada hakekatnya terdakwa tidak melakukan perbuatan seperti apa yang didakwakan padanya.

Hukum acara pidana Islam berpatokan pada asas hukum praduga tak bersalah (presumption of innocence). Asas yang mendasari bahwa seseorang yang dituduh melakukan suatu kejahatan harus dianggap tidak bersalah sebelum hakim dengan bukti-bukti yang menyakinkan menyatakan tegas kesalahannya itu. Artinya terdakwa tidak boleh dianggap sebagai pelaku atas perbuatan pidana yang didakwakan, mulai semenjak terdakwa diperiksa sebagai tersangka oleh penyidik sampai proses persidangan. Sebagaimana yang telah difirmankan oleh Allah Swt. dalam surat an-Najm ayat 38:

"(yaitu) bahwasanya seorang yang berdosa tidak akan memikul orang lain."

Menurut penulis, asas praduga tak bersalah yang kemudian diwujudkan dalam sistem pembebanan pembuktian kepada pihak penggugat atau Jaksa Penuntut Umum pada hukum acara pidana Islam, merupakan bagian dari penegakan hak asasi manusia. Islam memandang bahwa pada hakekatnya manusia sama di mata hukum, baik perlakuannya maupun status hukumnya.

\section{Simpulan}

Berdasarkan PP. Nomor 43 Tahun 2012 tentang Tata Cara Pelaksanaan Koordinasi, Pengawasan dan Pembinaan Teknis terhadap Kepolisian Khusus, Penyidik Pegawai Negeri Sipil, dan Bentuk-Bentuk Pengamanan Swakarsa, Penyidik Pegawai Negeri Sipil (PPNS) dalam hal ini yang dimiliki Komisi Pemberantasan Korupsi (KPK) mempunyai wewenang melakukan: penangkapan, penahanan, penggeledahan, penyitaan, dan pemeriksaan. Selain itu, KPK juga berwenang melakukan penyelidikan, penyidikan dan penuntutan terhadap tindak pidana korupsi. Untuk pembuktian dalam tindak pidana korupsi menimal harus ada dua alat bukti. Sebagaimana yang telah diatur dalam Undangundang Nomor 20 Tahun 2001 tentang Perubahan atas Undang-undang 
Nomor 31 Tahun 1999 tentang Pemberantasan Tindak Pidana Korupsi jo. Undang-undang Nomor 30 Tahun 2002 tentang Komisi Pemberantasan Tindak Pidana Korupsi (KPK).

Menurut Hukum Islam (fiqh murâfâât), Penyidik Pegawai Negeri Sipil (PPNS) setara dengan lembaga al-hisbah, yang petugas penyidiknya disebut al-Muhtasib dan al-Mutatawwi yang mempunyai wewenang untuk:

a. Mengawasi pelaksanaan undang-undang yang dibuat oleh pemerintah;

b. Mencegah tindak pidana yang terjadi masyarakat;

c. Melakukan penahanan sementara terhadap tersangka; dan

d. Melakukan penuntutan terhadap pelaku tindak pidana.

\section{Daftar Rujukan}

Al-Jauziyah, Ibnu Qayyim. Hukum Acara Peradilan Islam. Yogyakarta: Pustaka Pelajar, 2006.

Ash Shiddieqi, Muhammad Hasbi. Peradilan dalam Hukum Acara Islam. Semarang: Pustaka Rizki Putra, 1997.

Dahlan, Abdul Aziz, (et al). Ensiklopedi Hukum Islam. Jakarta: Icthiar Baru van Hoeve. Cet. IV. Jilid III, 2003.

Departemen Pertahanan RI. Al-Qur'an Terjemah Indonesia. Jakarta: Depertemen Pertahanan RI, 2001.

Djaja, Ermansjah. Meredesaian Pengadilan Tindak Pidana Korupsi. Jakarta: Sinar Grafika, 2010.

Djalil, Basiq. Peradilan Islam. Jakarta: Amza, 2012.

Hamzah, Andi. Perkembangan Hukum Pidana Khusus. Jakarta: Rineka Cipta, 1991.

---_----. Pemberantasan Korupsi Melalui Hukum Pidana Nasional dan Internasional. Jakarta: Raja Grafindo Persada, Cet. IV, 2008.

Hartono. Penyidikan \& Penegakan Hukum Pidana Melalui Pendekatan Hukum Progresif. Jakarta: Sinar Grafika, 2010.

Husein, Harun M. Penyidikan dan Penuntutan dalam Proses Pidana. Jakarta: Rineka Cipta, 1991.

Manan, Abdul. Etika Hakim dalam Penyelenggaraan Peradilan (Suatu Kajian dalam Sistem Peradilan Islam). Jakarta: Kencana, 2007. 
Marzuki, Peter Mahmud. Pengantar Ilmu Hukum. Jakarta: Kencana, 2009.

Mertukusumo, Sudikno. Mengenal Hukum. Yogyakarta: Liberty. Cet.II, 1999.

Moeljatno. Asas-Asas Hukum Pidana. Jakarta: Rineka Cipta, 1993.

Muslich, Ahmad Wardi. Pengantar dan Asas Hukum Pidana Islam (Fikih Jinâyah). Jakarta: Sinar Grafika, 2004.

Syamsuddin, Aziz. Tindak Pidana Khusus. Jakarta: Sinar Grafika, 2011.

Triwulan, Titik. Pengantar Ilmu Hukum. Jakarta: Prestasi Pustaka Publisher, 2006.

Tutik, Titik Triwulan. Hukum Tata Usaha Negara dan Hukum Acara Peradilan Tata Usaha Negara Indonesia. Jakarta: Kencana, 2011.

PP. No 43. Tahun 2012 tentang Tata Cara Pelaksanaan Koordinasi, Pengawasan, dan Pembinaan Teknis terhadap Kepolisian Khusus, Penyidik Pegawai Negeri Sipil, dan Bentuk-Bentuk Pengamanan Swakarsa

UU No. 8 Tahun 1981 tentang Hukum Acara Pidana (KUHAP)

UU tentang Kepolisian Negara Republik Indonesia No. 2 Tahun 2002 